\title{
The Analysis of Trickle Down Effect in Thailand
}

[Danuvas Sagarik]

\begin{abstract}
This study aims at discussing the economic development of Thailand regarding the trickle-down effect. Theoretically, it is posited that the development will take place from the industrialization, which generates income or capital to the owner of capital first and then will transmit to the lower income people. This study finds out that this theory is true to certain extent and there is still some controversial issues in the case of Thailand. (Abstract)
\end{abstract}

Keywords- Economic Development, International Development, Thailand, Public Poliy (key words)

\section{Introduction}

Reducing poverty has become the major concern in the world for the development of the countries. It has estimated that more than one billion of the population in the world suffer from poverty having less than 1 US\$ a day (15). Millennium Development Goals (MDG) highlighted the eradication of poverty reducing half of the people having less than a dollar a day and reducing the half of the people who is suffering from hunger.

Poverty relate to the economic growth as it creates opportunities for the people to reduce the poverty. In South East Asia and East Asia, Poverty reduction has been achieved mainly from economic growth (19). Optimistic accept that economic growth is essential to a country as the growth can be transmitted to the lower income families.

According to the trickle-down theory, businesses and other high income gain economic benefits letting the poor to acquire advantages (20).

Before financial crisis, Thailand achieved a significant level in economic growth. In the aftermath of the crisis, it reversed slightly and increased the number of poor (14). L.Cuyvers in his book "Globalization and social development: European and South East Asian evidence' has pointed out that there is economic growth in Thailand but not human resource development, also no trickle-down effect that lead for the economic development of the country (8).

This paper is to examine basically whether there is a trickle-down effect in Thailand. The findings of the research, contributes the idea of importance of trickling down for the developing countries to achieve their aim in reducing poverty. It reviews whether the poor in the country are getting benefits under this effect. Moreover, it studies the determinants of poverty and economic growth and analyzes how those related in reducing poverty of the country.

\section{Danuvas Sagarik}

Rangsit University

Thailand

\section{Literature Review}

\section{A. Concept and Characteristics of Trickledown Theory}

The trickle-down effect theory can be dated back to the work of classical economists such as Adam Smith and David Ricardo which their work suggested free market economy, deregulation and free trade. In the Wealth of Nations, Smith suggested how the free market economy can lead to economic growth, capital accumulation through market economy, competition, specialization, division of labor and productivity (25).

The trickle-down effect theory proposes that centering on tax cuts from the top class of the society such as the business owners, entrepreneurs and investors will benefit the whole population and economy. How it works is by introducing tax cuts policies, the topincome earners in the society will have more savings, thereby investing their savings in their companies and expending their businesses. The theory assumes that wealth from the rich people will trickle-down to the whole population through job creations. With their earned wages, the working class population will ultimately help drive the economy to grow faster through participating in the economics, the consumption.

McKay and Sumner pointed out that growth creates jobs providing opportunities for people to gain from higher education and moving out from the agricultural sector. Growth drives for the reduction in poverty. Poor can benefit from transformative public expenditures (16). Aghion and Bolton stated that it can be strengthen the trickling down in the economy through equality. Otherwise, when the inequality increases during the economic growth it can cause to risen the poverty in the economy (2).

According to Stiglitz, the unfair global trade regime slows down the development and unstable global financial system which poor countries find themselves with huge debt burdens (26). Stiglitz says that part of the wealth of the top in finance comes from exploiting the poor through predatory lending and abusive credit card practices. He therefore states that inequality leads to lower growth and less efficiency (26).

The issue of focusing on agriculture sector for tackling poverty and inequality is supported by the research work of Gafar. According to Gafar, (12) the statistic evidences from South American country, emphasis on Guyana, poverty is high in the rural areas and agriculture is the vital source of income for Guyana. Therefore Gafar suggested that poverty reduction policy should focus on the rural and agricultural development (12). Warr suggested that high number of percentage of the poor reside in the rural area, rely on agriculture as their main sources in Southeast Asia nations. Therefore, growth in agriculture sector would lead to reduction of poverty (28).

One of the influential thinkers of our time on human centered global development is Amartya Sen. His book 
"Development as Freedom" pointed out how freedom, equal access to resources and growth is crucial for human development. Poverty, as Sen (24) argued, is the "failure to achieve certain minimum capabilities." He also pointed out a number of recommendations for the policy makers in dealing with global development.

\section{B. Evidences on Trickle-down Effect}

Poverty considers declining generally when the economic growth rises. Growth increases the household income and it causes to reduce the poverty. Giving the benefits for the rich in the country their benefits can be transformed even to the poor is the main idea that should be considered here. For this, many scholars has argue giving both positive and negative responses regarding this.

Michael Roemer and Mary Gay (23) stated that economic growth helps poverty for each and every country in the world. Poor gain more benefits in the countries which grow up quickly. Economic growth is the best solution in reducing poverty (23). Policy implications and economic analysis are key factors in talking the relationship between poverty and economic growth. There should be a pure distribution method in reducing poverty in a country (6).

Dollar and Kraay (10), investigates 92 countries as a sample and emphasize that poorest average income changes in the same rate, when it changes the average income of all. This was clearly identified in all areas of the countries and was not limited to specific economic conditions or specific region. Thus his findings did not prove that economic growth can trickle down from rich to poor (10).

According to Seth Norton (18), Trickle-down is inaccurate. Growth should cascade and cannot trickle down. He emphasize the growth can be reduced the poverty of the country, but argue incomes of the poor increase more with the incomes of the rich people than vice versa. Trickle down is not for the growth and it is not to eliminate the poverty of a country (18).

Ravallion (21); Kakwani and Pernia (13) stated that economic growth is not the only element in reducing poverty and pointed out non income factors like health care and lack of access in education. The pattern and the manner of the benefits distribution are important to achieve the goal in poverty reduction.

According to Warr (28), poverty reduction related to agricultural growth but not for the industrial growth. He searched the poverty determinants in Indonesia, Thailand, Philippines and Malaysia for 39 years and identified that poverty is leading in the rural areas which is the major source of income is agriculture. Thus, the agricultural sector should be transformed to reduce the poverty (28).

\section{Methodology}

The data used in this study is taken from different international organizations and the surveys conducted by the office of the National Economic and Social Development Board (NESDB) Thailand. As the research used quantitative method to make it more reliable, government agencies and organizations supply the standard data especially when finding economic facts in the country. Basically, here it provides data for the minimum of thirty (30) years to make the comparison more reliable. Economic growth rate, unemployment, secondary education gross enrollment ratio, exports and FDI obtained from the World Bank and UN statistics. This organizational data mostly provides facts around twenty years and therefore even some data were taken from the national statistical office, which supplying the organizational statistics as indirect sources. Data which shows poverty incidence and inequality in the country were taken from the NESDB. It has determined the poverty and inequality in the household level and income, first in separate regions as municipal and non-municipal areas and finally as a whole region.

\section{Figure1. Conceptual Framework}

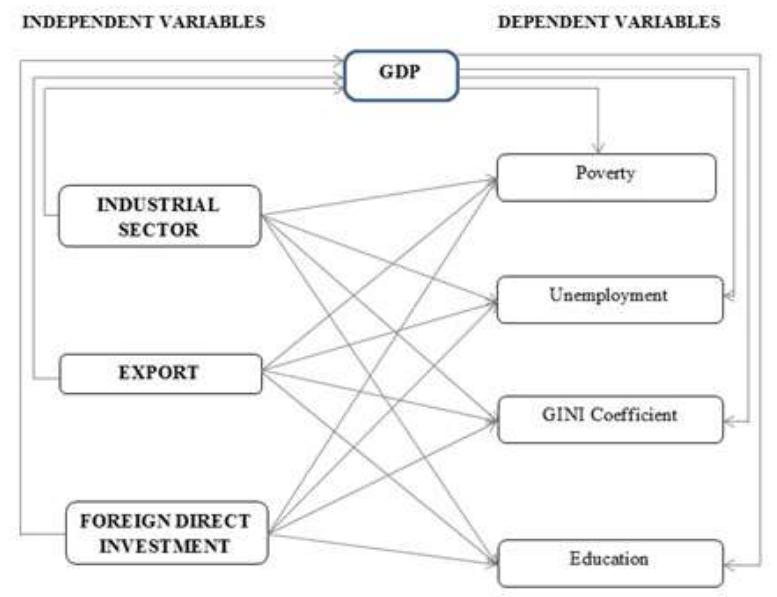

As shown by above figure, trickledown effect of a country is assumed to be correlated with above parameters. Industrial sector, export and foreign direct investment are the independent variables and related with the GDP of the country. GDP effects for the dependent variables like poverty, unemployment, Gini Coefficient and Education. Further, all three independent variables link with dependent variables defining, improvement of industrial sector, export and FDI in the country can correlate with poverty, unemployment, Gini Coefficient and education.

Multiple regression analysis is used to find out the estimations for the causal relationships between independent and dependent variables. There are altogether five estimations according $\mathrm{t}$ the number of dependent variables, namely poverty, unemployment, Gini coefficient, education, and GDP.

\section{Discussion}

In this discussion, the effect has been evaluated concerning key parameters that would be most likely to affect to the trickledown in Thailand. The parameters concerned are GDP, Industrial Sector, Country's export, and FDI concerns. In each main concern, the link with poverty, education, unemployment and GINI coefficient are evaluated. As per the theory, when the rich people or industries get benefits, poor people should also get the benefits. That is, if the trickledown is present, poverty should be controlled and shall positively increase the factors which help to mitigate poverty issues.

\section{Dependent Variable $=$ Poverty}


Proc. of The Second Intl. Conf. On Advances In Economics, Social Science and Human Behaviour Study - ESSHBS 2015 Copyright (C) Institute of Research Engineers and Doctors, USA .All rights reserved. ISBN: 978-1-63248-076-7 doi: 10.15224/ 978-1-63248-076-7-68

\begin{tabular}{|c|c|c|c|}
\hline Poverty & B & Beta & Sig \\
\hline GDP & -0.007 & -0.003 & 0.979 \\
\hline $\begin{array}{c}\text { INDUSTRIAL } \\
\text { SECTOR } \\
\end{array}$ & -0.001 & -0.797 & $0.039 *$ \\
\hline EXPORT & -0.084 & -0.143 & 0.730 \\
\hline $\begin{array}{c}\text { FOREIGN } \\
\text { DIRECT } \\
\text { INVESTMENT }\end{array}$ & 0.107 & 0.016 & 0.927 \\
\hline$R=0.923^{a}$ & & \multicolumn{2}{|c|}{ R Square $=0.852$} \\
\hline
\end{tabular}

2. Dependent Variable $=$ Unemployment

\begin{tabular}{cccc}
\hline Unemployment & B & Beta & Sig \\
\hline GDP & -0.072 & -0.273 & 0.119 \\
\hline $\begin{array}{c}\text { INDUSTRIAL } \\
\text { SECTOR }\end{array}$ & 0.000 & -0.983 & $0.049^{*}$ \\
\hline EXPORT & 0.017 & 0.249 & 0.703 \\
\hline $\begin{array}{c}\text { FOREIGN } \\
\text { DIRECT } \\
\text { INVESTMENT }\end{array}$ & -0.003 & -0.004 & 0.986 \\
\hline $\mathbf{R}=\mathbf{0 . 6 9 4}$ & & & \\
\hline
\end{tabular}

3. Dependent Variable $=$ GINI Coefficient

\begin{tabular}{cccc}
\hline $\begin{array}{c}\text { GINI } \\
\text { Coefficient }\end{array}$ & B & Beta & Sig \\
\hline GDP & 0.002 & 0.283 & 0.374 \\
\hline $\begin{array}{c}\text { INDUSTRIAL } \\
\text { SECTOR }\end{array}$ & $\begin{array}{c}2.192 \mathrm{E}- \\
007\end{array}$ & 0.069 & 0952 \\
\hline EXPORT & -0.001 & -0.346 & 0.786 \\
\hline $\begin{array}{c}\text { FOREIGN } \\
\text { DIRECT }\end{array}$ & 0.008 & 0.419 & 0.336 \\
INVESTMENT & & & \\
\hline $\mathbf{R}=\mathbf{0 . 3 2 6}{ }^{\mathrm{a}}$ & & $\mathbf{R}$ Square $=0.106$ \\
\hline
\end{tabular}

4. Dependent Variable $=$ Education

\begin{tabular}{cccc}
\hline Education & B & Beta & Sig \\
\hline GDP & 0.509 & 0.121 & $0.004^{*}$ \\
\hline $\begin{array}{c}\text { INDUSTRIAL } \\
\text { SECTOR }\end{array}$ & 0.002 & 0.819 & $0.000^{*}$ \\
\hline EXPORT & 0.155 & 0.152 & 0.396 \\
\hline $\begin{array}{c}\text { FOREIGN } \\
\text { DIRECT }\end{array}$ & -0.773 & -0.058 & 0.334 \\
$\begin{array}{c}\text { INVESTMEN } \\
\text { T }\end{array}$ & & & \\
\hline $\mathbf{R}=\mathbf{0 . 9 8 7 ^ { \mathbf { a } }}$ & & \multicolumn{2}{c}{ R Square $=\mathbf{0 . 9 7 5}$} \\
\hline
\end{tabular}

\section{Dependent Variable $=$ GDP}

\begin{tabular}{|c|c|c|c|}
\hline GDP & B & $\overline{B e t a}$ & Sig \\
\hline $\begin{array}{l}\text { INDUSTRIAL } \\
\text { SECTOR }\end{array}$ & 0.000 & 0.000 & 0.322 \\
\hline EXPORT & 0.128 & 0.186 & 0.497 \\
\hline $\begin{array}{c}\text { FOREIGN } \\
\text { DIRECT } \\
\text { INVESTMEN } \\
T \\
T\end{array}$ & -1.293 & 0.816 & $0.025 *$ \\
\hline $\mathrm{R}=0.481^{\mathrm{a}}$ & & R Squ & 0.232 \\
\hline
\end{tabular}

\section{Poverty}

The estimation on the determinants of poverty can be explained by the model quite well according to the R-square value of 0.852 . The only factor that significantly affects poverty is industrialization. That is, industrialization significantly reduces poverty. However, Export sector and FDI has no significant impact on poverty Thailand mainly has built successfully with the manufactured products and hence it directly affects poverty reduction of labors.

In Thailand, since 1970s, manufacturing sector is the largest recipient in international investment and agricultural sector is the smallest. National Statistical Office in Thailand estimated in 2014 that 38.49 million people in agricultural sector and 6.49 million in manufacturing sector. The gap in agricultural and manufacturing sector has become a serious problem for rural poverty and inequality. Therefore, in Thailand, trickledown effect can be present, with a high contribution from Industrial sector.

\section{Unemployment}

As for the determinants of unemployment, the model predicts about $48 \%$ of the changes in unemployment as seen from the R-square value of about 0.48 . This is a moderate estimation. Nevertheless, the estimation has shown that one variable affect unemployment significantly. Particularly, industrialization can significantly reduce unemployment whereas other variables have no significant effect. This estimation is in line with the estimation above considering the impact of industrialization on poverty. It can be seen that the trickle-down effect somewhat comes from the rise of industrial sector in the form of unemployment.

\section{GINI Coefficient}

Gini coefficient is a great indicator to provide information about inequality of the society. However, the estimation above in table 3 has illustrated clearly that all Gini coefficient are not determined significantly by any of the variables in the model. This can imply that the trickle-down effect may not work in the way that distributes the income more equally. The result is very interesting as the distribution of income may well be one of the main impacts that should be considered when discussion about trickledown effect.

\section{Education}

Education sector has shown a high degree of robustness of the estimation. GDP and industrialization greatly and significantly as well as positively affect enrollment rate. This implies that the development of the economy and the industry in a country provide greater opportunity for people to receive education. It may also imply that this happens because people earn more income and have higher ability to get education.

\section{GDP}

Gross Domestic Product or GDP is tested here as both independent and dependent variables in order to estimate the direct and indirect impact on other dependent variables. From the estimation here GDP is significantly affected by FDI. It is seen here also that higher GDP leads to higher school enrollment. Therefore FDI has indirect effect on enrollment rate through the rise of GDP. 


\section{v. Conclusions}

1. With existing data, it has shown that Thailand has shown some level trickledown effect.

2. Industrialization has obviously reduced poverty and generated employment as well as higher school enrollment rate.

3. Even though poverty and unemployment may be reduced as country industrialized, but the income gap has not been narrowed. The trickle-down effect in Thailand is not represented in terms of income redistribution.

4. Especially, country policies should be evaluated and reviewed in order to give more concessions to the Industrial Sector.

\section{References}

[1] Adams, R. H., \& Page, J. (2003). International migration, remittances, and poverty in developing countries (Vol. 3179): World Bank Publications.

[2] Aghion, P., \& Bolton, P. (1997). A theory of trickle-down growth and development. The Review of Economic Studies, 64(2), 151-172.

[3] Ahluwalia, M. S. (1976). Inequality, poverty and development. Journal of development economics, 3(4), 307-342.

[4] Alesina, A., \& Perotti, R. (1996). Income distribution, political instability, and investment. European Economic Review, 40(6), 1203-1228.

[5] Bagchi, S., \& Svejnar, J. (2014). Does Wealth Inequality Matter for Growth? The Effect of Billionaire Wealth, Income Distribution, and Poverty.

[6] Bourguignon, F. (2000). The pace of economic growth and poverty reduction. Delta.

[7] Bruno, M., Ravallion, M., \& Squire, L. (1998). Equity and growth in developing countries: old and new perspectives on the policy issues. Income distribution and high-quality growth, 117-146.

[8] Cuyvers, L. (2001). Globalization and Social Development. UK: Edward Elga Publishing Limited.

[9] Deininger, K., \& Squire, L. (1997). Economic growth and income inequality: reexamining the links. Finance and Development, 34, 38 41.

[10] Dollar, D., \& Kraay, A. (2002). Growth is Good for the Poor. Journal of economic growth, 7(3), 195-225..

[11] Frank, A. G. (1966). The development of underdevelopment: New England Free Press.

[12] Gafar, J. (1998). Growth, inequality and poverty in selected Caribbean and Latin American countries, with emphasis on Guyana. Journal of Latin American Studies, 30(03), 591-617.

[13] Kakwani, N., \& Pernia, E. M. (2000). What is pro-poor growth? Asian development review, 18(1), 1-16.

[14] Kakwani, P. (2000). What is pro-poor growth. Asian Development Review, 18(1), 16

[15] Kingsbury D, M. J., Hunt,McGillivray.M,Clarke. (2008). International Development: Issues and Challenges. 373.

[16] McKay, A., \& Sumner, A. (2008). Economic growth, inequality and poverty reduction: does pro-poor growth matter? : IDS

[17] Neuhaus, M. (2006). The impact of FDI on economic growth: an analysis for the transition countries of Central and Eastern Europe: Springer.

[18] Norton, S. W. (2002). Economic growth and poverty: in search of trickle-down. Cato J., 22, 263.

[19] Parel, D. K. C. (2014). Growth and Redistribution: Is there 'Trickle Down Effect in the Philippines. Philipines.

[20] Philippe Aghion, P. B. (1997). A theory of Trickle Down growth and development. Economics Studies, 64(2), 23.

[21] Ravallion, M. (1995). Growth and poverty: evidence for developing countries in the 1980s. Economics letters, 48(3), 411-417.

[22] Reyes, C., Tabuga, A., Mina, C., Asis, R., \& Datu, M. (2011). Dynamics of Poverty in the Philippines: Distinguishing the Chronic from the Transient Poor: Philippine Institute for Development Studies.

[23] Roemer, M., \& Gugerty, M. K. (1997). Does economic growth reduce poverty? CAER II.
[24] Sen, A. (1999). Development as freedom: Oxford University Press.

[25] Smith, A. (1937). The wealth of nations [1776]: na.

[26] Stiglitz, J. (2006). We have become rich countries of poor people. Financial Times, 8.

[27] Van Dijck, P., Verbruggen, H., \& Linnemann, H. (1987). Exportoriented industrialization in developing countries: NUS Press.

[28] Warr, P. (2001). Poverty reduction and sectoral growth: evidence from Southeast Asia. Paper presented at the WIDER Development Conference on Growth and Poverty, Helsinki. 